\title{
OVERVIEW OF BIM APPLICATION FOR BRIDGE - HIGHWAY AND INFRASTRUCTURE PROJECTS IN VIET NAM
}

\author{
Ngo Thanh Thuy ${ }^{1}$, Do Minh Truyen ${ }^{2, *}$, Huynh Xuan Tin ${ }^{1}$ \\ ${ }^{1}$ Campus in Ho Chi Minh City, University of Transport and Communications, No. 450-451 Le \\ Van Viet Street, Tang Nhon Phu A Ward, District 9, Ho Chi Minh City, Vietnam \\ ${ }^{2}$ V7 Engineering And Technology Company Limited CO.LTD, No 448/5E Le Van Viet \\ Street, Tang Nhon Phu A Ward, District 9, Ho Chi Minh City, Vietnam

\section{ARTICLE INFO} \\ TYPE: Scientific communication \\ Received: $28 / 5 / 2020$ \\ Revised: $30 / 8 / 2020$ \\ Accepted: 31/8/2020 \\ Published online: 30/9/2020 \\ https://doi.org/10.47869/tcsj.71.7.3 \\ * Corresponding author \\ Email: dominhtruyen10497@gmail.com; Tel: 0934017137
}

\begin{abstract}
In recent years, the industrial revolution 4.0 has been strongly happening and affecting many industries and fields thanks to the rapid development of science and technology. Many new technologies have been developed and applied in the construction industry, increasing labor productivity and work efficiency, and reducing construction waste. One of these new technologies is Building Information Modeling (BIM), which is being strongly developed and evaluated as a key technology for the construction industry. BIM defines all property information related to a full lifecycle of a target structure, from planning and design to construction, operation, and maintenance. In Vietnam, BIM has been effective for certified projects using state budget, private capital, or foreign investment. The goal of this paper is to provide a comprehensive, up-to-date literature review. In addition to that, research areas regarding BIM for bridge, highway, infrastructure, and some applications in this domain in Vietnam are presented and discussed.
\end{abstract}

Key words: Building Information Modeling (BIM), bridge design, BIM for infrastructure (InfraBIM), project life cycle, level of development (LOD).

(C) 2020 University of Transport and Communications

\section{INTRODUCTION}

The concept of Building Information Modeling (BIM) rising in the 1970s, and gradually gained popularity when Autodesk (an American software company) published it's research on digital in construction in the 1990s [1,2]. BIM, as defined by the U.S. National Building 
Information Model Standard Project Committee, "is a digital representation of physical and functional characteristics of a facility. A BIM is a shared knowledge resource for information about a facility forming a reliable basis for decisions during its life cycle; defined as existing from earliest conception to demolition" [3]. BIM is not only a proprietary software product or program, but also an integrated process, built on reliability and collaborative information for project life cycle from design, construction to operation of a project [4]. Until now, BIM has become the mainstream construction technology in many countries around the world. In Europe many countries such as the UK, Finland, Norway, the Netherlands, Denmark, France, Australia, and Germany are also applying BIM in public construction investment. Meanwhile, in Asia, South Korea, Hong Kong, and Singapore are required to apply BIM in the construction industry in the public sector, basing on their own standards and a roadmap for BIM implementation. Vietnam has issued Decision No. 1057 / QD-BXD Temporary Guidance on the Application of Building Information Modeling (BIM) during the pilot phase [6] and organized training programs on BIM for construction engineers as well as management units [5]. BIM can apply many fields such as design, construction and project management to solve the problems of material wastage, low productivity, and poor information exchange. BIM defines all property information related to a full lifecycle of a target structure, from planning and design to construction, operation, and maintenance, in terms of technology of construction, production, management, and utilization. BIM provides faster design changes; optimizes designs with analysis, simulation and visualization; and higher quality building documents. Moreover, it allows designers to extract valuable data from the model to facilitate earlier decision-making and more economical project delivery. A BIM model, generating by such technology, is a virtual structure built with 3D graphic data and non-graphic data or property information. BIM helps to decrease from $5 \%$ to $20 \%$ of initial investment cost and about $30 \%$ of operation and maintenance cost [1]. In Vietnam, looking at the roadmap of the BIM project in construction and operation management together with the Prime Minister's Decision 2500 / QD-TTg, it can be seen that BIM is creating all conditions to apply with the highest possible level in the shortest time, including legal corridors, guidelines and regulations, and technical BIM standards [7]. Up to now, there have been about 20 new bridge - highway and infrastructure projects, applying BIM in construction design and management, and at least 12 important projects with complex technical requirements applying BIM in the project life cycle.

\section{BIM APPLICATION FOR BRIDGE - HIGHWAY AND INFRASTRUCTURE PROJECTS}

BIM is widely becoming a competent tool in the construction industry and it's applied to the entire life cycle of buildings [8,9,10-12]. BIM is not only just a geometrical representation of a building but also an intelligent virtual 3D model of the building as it contains all information about every component for its whole life cycle $[13,14,15]$. It improves the quality and accuracy of drawings, as well as constructability, and enhances collaborations [9, 16]. BIM has helped the government and infrastructure managers to navigate away from traditional and human-based activities into automatic operations to enhance the precision, 
quality, and safety of the project. Some of the technologies that have been applied to BIM models, such as laser scanning and virtual reality for project planning, bidding, and constructions. Laser scanning helps in inspection and as-built documentation of infrastructure due to higher accuracy and speed of operation [17,18,19-21]. Through stitching different captures, laser scanners produce a point cloud model of the infrastructure that has to a highprecision, resolution, and could be used for modeling [22]. Laser scanners can scan the surfaces of the road regularly during the construction phase to help monitoring the project's progress based on their schedules such as the National Highway \#1 project in Quang Tri, SPSSA international terminal project in Ba Ria - Vung Tau province, Hyosung Vina chemicals port project in Ba Ria - Vung Tau province. Virtual reality (VR) technology is created from the BIM model of the project. VR helps to enhance the benefits that could be obtained from the $3 \mathrm{D}$ models while helping the investor, stakeholders have a detailed and intuitive view before construction.

\subsection{BIM application for bridge - highways projects}

In Vietnam, earlier BIM application bridge-highway projects have not fully taken advantage of the BIM model, seldomly combined the overall power of the solution chain. The customer has not clearly defined what is a good and poor quality BIM model. The solution to the application of BIM in Vietnam is the design coordination method [23]. In addition, the use of additional digital such as 3D laser scanner allows scanning inside the model to find the difference between the building under construction and design model. Partners and stakeholders, such as investors, contractors, design consultants, supervision consultants, state management agencies, financial and banking institutions have been accurately, directly, timely connected and shared information through the CDE environment with 3D visual works.

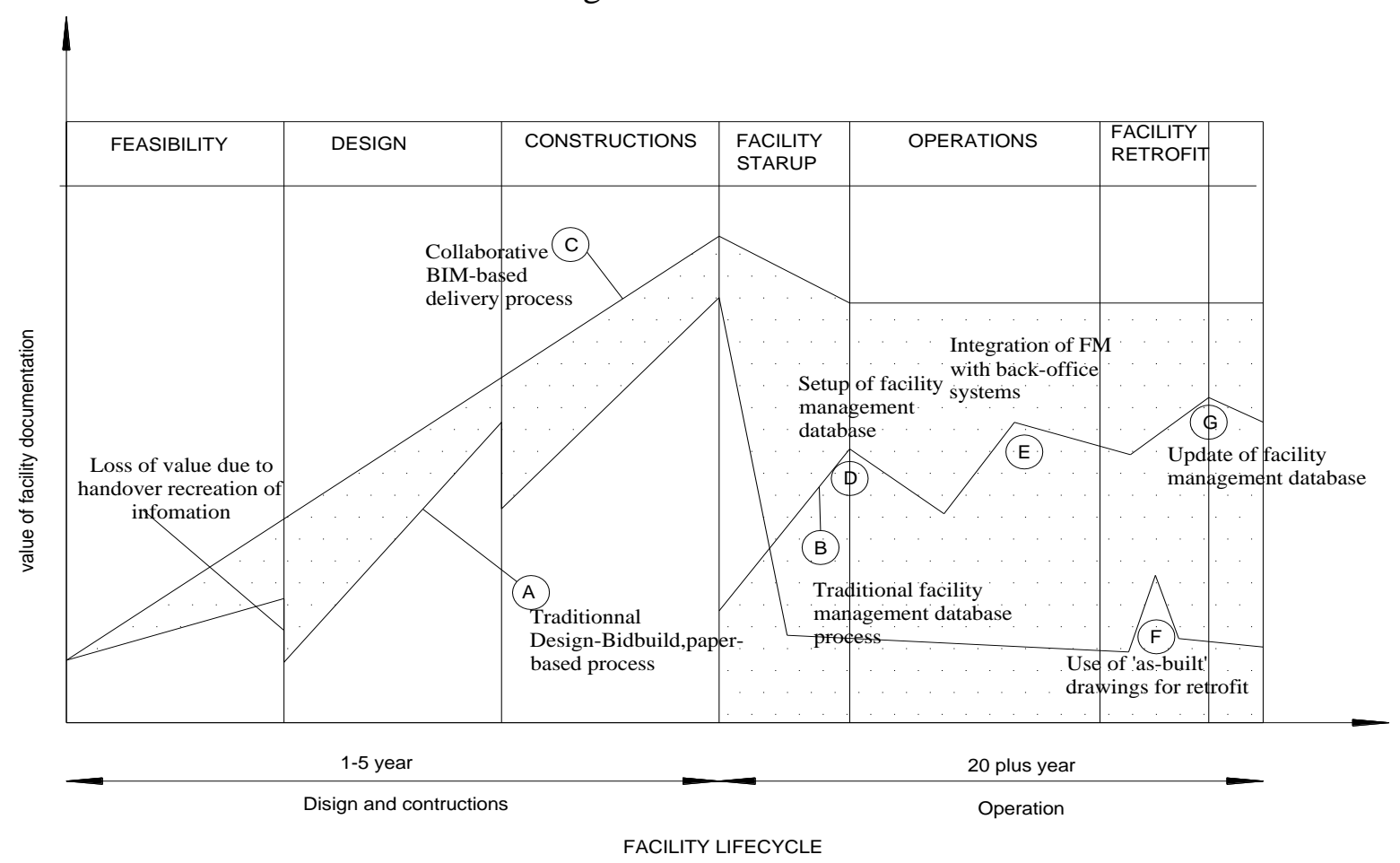

Figure 1. Construction life cycle, according to FHWA-HIF-16-011 (2016) [25]. 
BIM helps eliminate almost completely design conflicts in the construction process, leading to accelerating the construction schedule, reducing repair costs, and minimizing the risks during the construction process. It can analyze and make simulations of design models quickly for the optimal design.

Figure 1, shows the benefits of BIM over traditional processes. The later, through many stages for transferring from person to person with paper (2D), has made the loss of information at the transition stages, especially the transfer of 2D models by drawings. If there is a design mistake, it's usually come back to an earlier stage for a solution. In contrast, BIM model helps the exchanged-information process being continuous one phase after another. As a results, there is no loss of information; saving a large amount of cost and time; increasing the ability of information-coordination; increasing cooperation among stakeholders; and improving the information-coordination at the design, construction and life cycle stages. BIM provides a clear overview of the project to stakeholders' appropriate decisions, reduces risks, and improves work efficiency and the parties' interaction with the model. As a result, the BIM processing speed is faster than the traditional method [24].

BIM allows unprecedented cooperation in design activities and gives all contractors the opportunity to sit down and work on issues before construction begins. BIM is used to build three-dimensional spatial models with architectural models, structural models, electrical, water, and air-conditioning engineering network models. All members of the construction project will work together in a common space to find conflicts between parts and components of the work, and to achieve solutions to such conflicts. BIM acts as the most appropriate and useful way to create a system of construction drawings with high accuracy, leading to a minimum reduction of costs incurred at site.

With the use of BIM, project members can clearly know what other members are doing with the project. This is particularly useful in cases where "stacking of trades" can lead to a "conflict" - the area in which two different contractors plan to install equipment or materials in same space, sometimes the same time. However, if these "conflict" issues are included in the BIM model, this problem can be fully anticipated and can be solved before the work is carried out [24].

Moreover, BIM helps to explore different construction options, construction sequences, or workable parts of the construction work as well as the whole project. At the same time, BIM creates a three-dimensional model with full information for all parts of the building from shape, size to material structure and finishing. This leads to easily calculate the volume for estimate and project timeline. BIM adds value and reduces waste by providing a tool for exploring the layout of cranes, materials, as well as temporary structures on construction sites.

BIM promotes greater cooperation in the early stages of a project among team members through the use of more relevant and comprehensive information, more effectively than traditional methods. This allows design decisions are optimal in terms of time and cost, and fewer changes in the design or during construction, when even small changes are possible has a great impact on both construction costs and the life cycle costs [25]. 
The information built in the BIM model can be changed according to user preferences because of its parametric information. When there is a need for modifying design or model, the relevant objects such as volume, drawings, and calculations will be automatically updated. This will be very effective with designs that require a lot of modifications during the approval process as well as the actual construction. In addition, BIM gives project participants opportunities to contact with others right away at the time of inconsistent issues discovering. This helps the design become accurate, minimizing the possibility of project errors. In addition, the application of BIM brings economic benefits to all stakeholders. Contractors can benefit from the use of BIM through the coordination of the parties, better cost of management and procurement, and faster manufacturing of components through automatically transferring information from BIM model [25].

To create a BIM model, it usually takes three main model levels: Architectural model, calculation model, and structural model. The first model is at the idea step. The calculation model is after the plans being approved in terms of architecture and structural engineers will convert architectural models into calculation models to test the structural capacity. The structural model is for calculation with specific structural, reinforcement, and other details. From the structural model, mass as well as other material quantity will be exported for actual construction [26].

\subsection{BIM application for infrastructure projects}

It can be seen that the application of BIM technology in Vietnam for the infrastructure is quite new, and the stakeholders are quite skeptical about BIM's application process and its feasibility compared with traditional design. InfraBIM application is applied after civil construction works, but it is developing rapidly. The report "Business performance of BIM applications for infrastructure projects" McGraw-Hill in the U.S as follows:

- $67 \%$ of all BIM users report a positive ROI for using BIM on infrastructure projects.

- Companies using BIM applications for infrastructure projects have a double growth rate (from $27 \%$ to $46 \%$ ).

- $89 \%$ of units are using BIM and will continue to use BIM for their upcoming infrastructure projects.

- 78\% of enterprises that have not used BIM are very interested in using BIM for new projects [23].

The potential of BIM application for technical infrastructure works in Vietnam is enormous. In order to promote BIM integration for the life cycle of investment infrastructure projects, the role of State agencies is very important, especially when the technical infrastructure is the main focus of the public investment. So that the completion of the legal corridor as well as the system of standards, BIM standards must be at the forefront. InfraBIM is used for many different purposes throughout the life of the projects. Autodesk has analyzed and summarized the benefits that InfraBIM brings in typical phases including planning, design, construction and operation of technical infrastructure works as follows [27]:

The planning phase of an infrastructure project begins with existing conditions and massive amounts of data. Gathering and understanding the constraints of nearby assets and 
landforms along with regulatory considerations can be costly overwhelmed by InfraBIM. Right away, a BIM approach can improve the accuracy and speed of the planning process by helping to aggregate multiple types of data from a variety of sources into a single reference model, and be used throughout the life cycle of a project. This comprehensive view of existing conditions provides all stakeholders with greater clarity - which can help inform their decisions and further speed of planning process. Adopting BIM from the planning stage can simplify communication while enhancing collaboration between different stakeholders. Applying time (4D) and cost (5D) planning in infrastructure projects can make greater value. The more complex and larger the project is, the more benefit is earned [28,29].

The design phase consists of conceptual and detailed design. In the conceptual design, BIM allows designers working with 3D models simulating actual conditions for confidence of choosing the right options. Integrated project models facilitate whole-project visualization, clash detection, and construction planning. BIM has helped in the real-time evaluation of design criteria and rule checking and has supported the quality of design [16,28,30-41]. BIM can help in different phases of design that include preliminary design, detailed design, and design optimization [42]. In addition, significant improvements in the design process, reduced omissions and errors, and subsequent reduction of conflicts and coordination problems in the construction site are most favored benefits of using BIM in infrastructure from the design stage [36]. BIM can greatly help in the phase of structural design and analysis of the project life cycle [36,43-45]. BIM capabilities in project visual scheduling (4D) and automatic and detailed cost estimations (5D) made a revolution in the building process from the design stage. Application of BIM for infrastructure design and management of the project in scheduling, and procurement has been enhanced to reduce resource waste [14,31,44]. Level of development (LOD) and level of information (LOI) are the most important criteria in the design phase that can significantly influence project delivery and its quality [46]. LOD defines the expected level of precision in the representation of different elements of a $3 \mathrm{D}$ model of building and infrastructure [47]

During the construction phase using the BIM process, the design model is available earlier to better inform preconstruction planning for activities such as staging, sequencing, scheduling, quantity take-off, and estimating. Given access to the model, contractors can produce more accurate bids in less time. Construction operations are also facilitated by the BIM process, as data can be added to the model to support schedule (4D) and cost (5D) project management. Using BIM during construction of infrastructure and bridges can reduce the number of requests for information (RFIs) and change orders (COs). BIM can help in producing detailed bill of materials and improve the financial performance during the construction phase. Monitoring of construction with BIM can help in prevention of contract disputes during the construction [48-51]. As the design and construction documents are linked in the BIM model, evaluation of alternatives and change management is easier during construction [48]. Using BIM can be a significant help in construction of bridges. Parametric modeling of bridges can improve the quality of design and prevent unnecessary and duplicate information, which benefits construction, erection, and fabrication crew, as well as designers 
and owners [52]. BIM preserves and uses information over the entire life cycle of technical infrastructure, allowing investors to better manage projects.

The operation and maintenance phase of the infrastructure asset will persist longer than any other project phases, so the advantages gained here have cumulative effects. Using BIM process operators has access to the richest information streams ever created, including detailed data from the post-construction model and information from real-time sensors that continuously update the model during operation.

\section{CHALLENGES IN APPLYING BIM FOR BRIDGE - HIGHWAY AND INFRASTRUCTURE}

In Vietnam, many investors as well as contractors, consulting companies have bravely used BIM for their projects with different levels. For example, the project of Metro \#2 Ben Thanh - Tham Luong, National Highway \#1 section in Quang Tri, Sai Gon 2 Bridge project, Thu Thiem Tunnel project, ... In addition, there is a 550 - Binh Duong overpass applies to Revit building a 3D model includes 5 spans of 40m-length and $16 \mathrm{~m}$-width with steel box girders and concrete for detailed design stage (Figure 2,3).

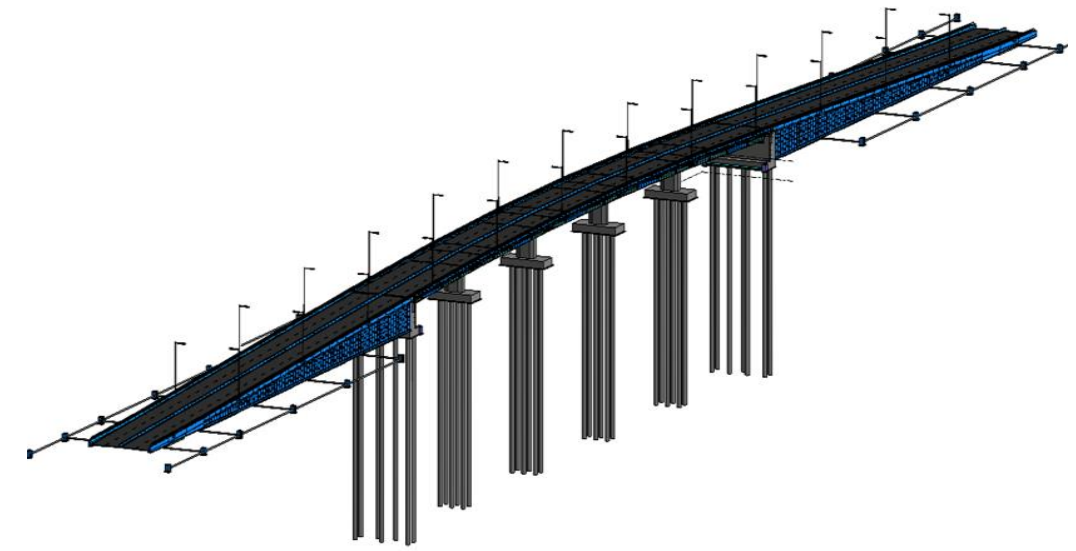

Figure 2. 3D model 550 - Binh Duong overpass using Autodesk Revit.

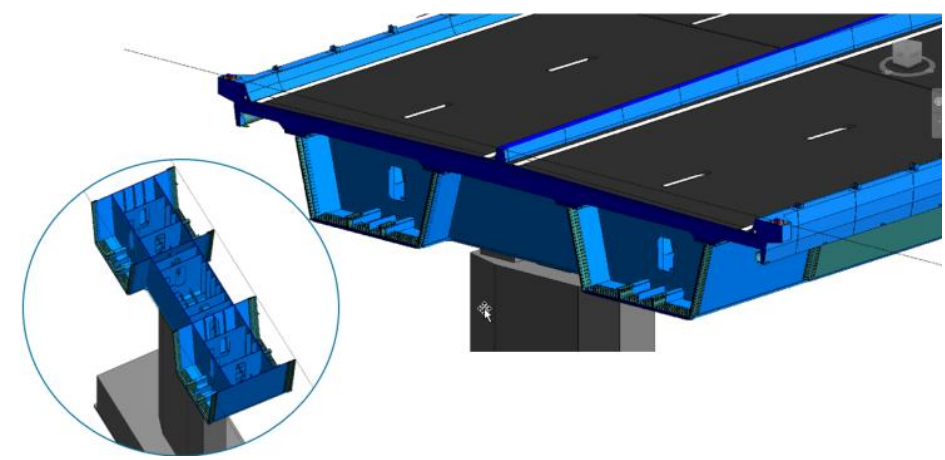

Figure 3. The detailed of steel-girders module on top of pillar.

BIM can help in design, planning, and maintenance of roads and highways. BIM was used in Ben Luc - Long Thanh highways for the development of a platform using in the project life cycle. BIM can help in planning and detailing as well as sequencing and managing the workflow [53]. The repeating tasks of rules and codes in design could be automated by using BIM. Surveying a number of projects, such as Thu Thiem 2 Bridge, Song Chua Bridge, 
Ben Luc - Long Thanh highways, Vam Cong Bridge, reviews that BIM application has helped investors shorten the schedule and save costs through optimization and handling of difficulties in each stage of construction. Therefore, it is necessary to accelerate the process of approaching BIM for the construction industry and the bridge industry, in particular, to contribute to the country's development process.

In general, BIM has become the core technology used in the construction industry and construction of technical infrastructure in particular. The application of a new technology involves many challenged and the efficiency can be reduced by the risk factors faced [54]. The research team presents a number of challenges to face when applying BIM by many authors, in Table 1:

Table 1. Challenges faced when applying BIM.

\begin{tabular}{ccl}
\hline Serial & Challenge team & \multicolumn{1}{c}{ Kind of a challenge } \\
\hline $\mathbf{1}$ & Personnel & - Lack of experience with projects applying BIM; Shortages of \\
& skilled personnel [55, 56, 57]
\end{tabular}

In summary, the application of BIM in a technical infrastructure project faces many challenges as mentioned in Table 1. However, these challenges are even greater due to the specific characteristics of the technical infrastructure work such as a large amount of data. On the other hand, the application of BIM for technical infrastructure is still new compared to the 
application of BIM for civil and technical constructions, leading to cultural and cognitive barriers.

\section{ACTUAL APPLICATION AND USED OF BIM FOR TECHNICAL INFRASTRUCTURE WORKS IN VIETNAM}

In Vietnam, the information on infrastructure works is scattered in many different departments and branches. This leads to the difficulties of collecting input data; prolonging the investigation and survey process; decentralizing information management. As a result, the database system is inaccurate and uniform, causing disputing during the implementation process technical infrastructure projects, especially investment projects on construction of roads in major cities, of which particularly painful are issues related to site clearance [54]. BIM and its advantages can solve all the problems mentioned above if InfraBIM is applied properly and comprehensively. Investment in constructing technical infrastructure works, especially bridges and highway, has been carried out since a few years ago. A study carried out in 2020 on the development of a BIM project roadmap has listed a number of projects that use BIM in Vietnam, in which there are 12 technical infrastructure projects, specifically (Table 2).

After studying a number of technical infrastructure works using BIM in Vietnam, it is seen that BIM has been mainly used for transport engineering infrastructure (bridges, roads, ports), large-scale projects and high capital in Vietnam projects. However, BIM applications are mainly focusing on building 3D models to control conflicts, providing a visual perspective for project participants. Other applications are project documentation, tendering, or volume separation. For the long run, it is needed to promote the application of different BIM applications for technical infrastructure works with the goal of creating a basic system detailed data, for management, as well as construction [54]. Currently, in addition to visualizing construction works through the creation of 3D models, BIM are also capable for many different purposes in the life cycle of infrastructure projects, mainly during the feasibility study phase, the design phase, and the operation phase.

Table 2. Selected Bridge - Highway and Technical infrastructure applied BIM.

\begin{tabular}{|c|c|c|c|c|}
\hline Serial & Project & Scale works & Using BIM & $\begin{array}{l}\text { Evaluate } \\
\text { the use } \\
\text { results }\end{array}$ \\
\hline 1 & $\begin{array}{l}\text { Metro\#2: Ben Tham } \\
\text { - Thanh Luong } \\
\text { project in HCM city. }\end{array}$ & $\begin{array}{l}\text { Total investment of } 1,8 \\
\text { billion USD. }\end{array}$ & $\begin{array}{l}\text { 3D model in construction } \\
\text { preparation phase. }\end{array}$ & - \\
\hline 2 & $\begin{array}{l}\text { National Highway } \\
\# 1 \text { project in Quang } \\
\text { Tri. }\end{array}$ & $\begin{array}{l}\text { Total investment of } \\
128,3 \text { million USD. }\end{array}$ & $\begin{array}{l}\text { 3D model and 3D laser } \\
\text { scanning in the planning } \\
\text { stage and progressing to } \\
\text { application in construction. }\end{array}$ & - \\
\hline 3 & $\begin{array}{l}\text { Sai Gon } 2 \text { Bridge } \\
\text { project. }\end{array}$ & $\begin{array}{l}1-\mathrm{km} \text { long of } 30 \text { spans } \\
\text { and } 23.5 \mathrm{~m} \text { width of } 6 \\
\text { lanes, including } 4 \text { lanes } \\
\text { for cars. }\end{array}$ & $\begin{array}{l}\text { BIM service is used in the } \\
\text { process of making bidding } \\
\text { documents and volumes, 3D } \\
\text { models and presentation } \\
\text { data. }\end{array}$ & Good \\
\hline
\end{tabular}


Transport and Communications Science Journal, Vol. 71, Issue 7 (09/2020), 760-774

\begin{tabular}{|c|c|c|c|c|}
\hline Serial & Project & Scale works & Using BIM & $\begin{array}{l}\text { Evaluate } \\
\text { the use } \\
\text { results } \\
\end{array}$ \\
\hline 4 & $\begin{array}{l}\text { Thu Thiem Tunnel } \\
\text { project across the } \\
\text { Saigon River [60] }\end{array}$ & $\begin{array}{l}\text { Total investment of } \\
347,7 \text { million USD. }\end{array}$ & $\begin{array}{l}\text { 3D model and conflict } \\
\text { control in post-construction } \\
\text { processes, or operations and } \\
\text { use. }\end{array}$ & 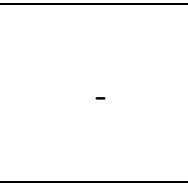 \\
\hline 5 & $\begin{array}{l}\text { Thu Thiem } 2 \text { Bridge } \\
\text { project crosses the } \\
\text { Saigon River in } \\
\text { HCM city. }\end{array}$ & $\begin{array}{l}\text { Designing } 06 \text { lanes, the } \\
\text { width of the main } \\
\text { bridge is } 27.3 \mathrm{~m} \text { width } \\
\text { of length of } 1,465 \mathrm{~m} \text {, of } \\
\text { which the cable-stayed } \\
\text { bridge section is } \\
885.7 \mathrm{~m} \text { long, with the } \\
\text { main tower } 113 \mathrm{~m} \text { high. }\end{array}$ & $\begin{array}{l}\text { 3D model and conflict } \\
\text { control in post-construction } \\
\text { processes, construction } \\
\text { profile, volume extraction } \\
\text { model and completion model } \\
\text { during the construction } \\
\text { phase, or operation and use. }\end{array}$ & Good \\
\hline 6 & $\begin{array}{l}\text { Song Chua bridge } \\
\text { project in Phu Yen } \\
\text { province. }\end{array}$ & $\begin{array}{l}\text { Total investment of } \\
158 \text { million USD. }\end{array}$ & $\begin{array}{l}\text { Application for survey, } \\
\text { design, construction and } \\
\text { completion stages. }\end{array}$ & - \\
\hline 7 & $\begin{array}{l}\text { Ben Luc - Long } \\
\text { Thanh highway in } \\
\text { Long An provine } \\
\text { and HCM city. }\end{array}$ & $\begin{array}{l}\text { Package A2-1, design } \\
\text { speed of } 100 \mathrm{~km} \mathrm{/} \mathrm{h,} \\
33 \mathrm{~m} \text { width cross } \\
\text { section with } 4 \text { lanes, } 2 \\
\text { emergency stopping } \\
\text { lanes. }\end{array}$ & $\begin{array}{l}\text { 3D model and conflict } \\
\text { control during the design } \\
\text { phase and construction } \\
\text { preparation. }\end{array}$ & Good \\
\hline 8 & $\begin{array}{l}\text { Vam Cong Bridge } \\
\text { project in Dong } \\
\text { Thap province and } \\
\text { Can Tho city }\end{array}$ & $\begin{array}{l}\text { Total investment of } \\
272 \text { million USD. }\end{array}$ & $\begin{array}{l}\text { 3D model, construction } \\
\text { profile, volume extraction } \\
\text { model and completed model } \\
\text { in the construction phase. }\end{array}$ & - \\
\hline 9 & $\begin{array}{ll}550-\text { Binh } & \text { Duong } \\
\text { overpass } & \text { project } \\
{[61]} & \end{array}$ & $\begin{array}{l}\text { Design } 5 \text { spans } 40 \mathrm{~m} \text {, } \\
\text { global width } 16 \mathrm{~m} .\end{array}$ & $\begin{array}{l}\text { Experimental 3D model in } \\
\text { detailed design stage, and } \\
\text { virtual reality (VR) products } \\
\text { supporting for project } \\
\text { manager }\end{array}$ & $\begin{array}{c}\text { Experimen } \\
\mathrm{t}\end{array}$ \\
\hline 10 & $\begin{array}{l}\text { My Thuy } \\
\text { Intersections in Ho } \\
\text { Chi Minh City }\end{array}$ & $\begin{array}{l}\text { Including works: Ky } \\
\text { Ha } 3 \text { bridge of } 4 \text { lanes, } \\
\text { length of } 75 \mathrm{~m} \text {; the left } \\
\text { turn tunnel consists of } \\
2 \text { lanes, length of } 405 \\
\mathrm{~m} \text {, the closed tunnel } \\
\text { section is } 80 \mathrm{~m} \text { long; } \\
\text { Overpass on the belt } 2 \\
\text { consists of } 4 \text { lanes, } \\
\text { length of } 316 \mathrm{~m} \text {; My } \\
\text { Thuy } 3 \text { bridge of } 6 \\
\text { lanes, length of } 124 \mathrm{~m} \text {; } \\
\text { Turn left overpass, and } \\
\text { Ky Ha } 4 \text { bridge. }\end{array}$ & $\begin{array}{l}\text { 3D model and 3D laser } \\
\text { scanning in the planning } \\
\text { stage and progressing to } \\
\text { application in construction. } \\
\text { The virtual reality (VR) } \\
\text { products supporting for } \\
\text { project manager }\end{array}$ & $\begin{array}{c}\text { Experimen } \\
\mathrm{t}\end{array}$ \\
\hline 11 & $\begin{array}{l}\text { SP-SSA } \\
\text { international } \\
\text { terminal (SSIT) in } \\
\text { Ba Ria - Vung Tau }\end{array}$ & $\begin{array}{l}\text { Total area: } 60.55 \mathrm{ha}, \\
\text { Container berths: } 2 \text {, } \\
\text { Quay length: } 600 \mathrm{~m} \text {, } \\
\text { Container ships with }\end{array}$ & $\begin{array}{l}\text { Structural inspection, 3D } \\
\text { Laser Scan, Detailed design } \\
\text { for demolition and } \\
\text { resconstruction work. Project }\end{array}$ & Good \\
\hline
\end{tabular}


Transport and Communications Science Journal, Vol. 71, Issue 7 (09/2020), 760-774

\begin{tabular}{|c|c|c|c|c|}
\hline Serial & Project & Scale works & Using BIM & $\begin{array}{l}\text { Evaluate } \\
\text { the use } \\
\text { results }\end{array}$ \\
\hline & province & $\begin{array}{l}\text { load up } \\
160,000 \mathrm{DWT} .\end{array}$ & $\begin{array}{l}\text { Management } \\
\text { Construction Supervision for } \\
\text { the SSIT's berth after } \\
\text { collision incident of the } \\
\text { Fareast Honesty Vessel. }\end{array}$ & \\
\hline 12 & $\begin{array}{l}\text { Hyosung Vina } \\
\text { chemicals port in Ba } \\
\text { Ria - Vung Tau } \\
\text { province }\end{array}$ & $\begin{array}{l}\text { Total area: 10ha; Jetty } \\
\text { for } 60.000 \mathrm{DWT} \text { LPG } \\
\text { Tankers. }\end{array}$ & $\begin{array}{l}\text { 3D model, construction } \\
\text { supervision, and laser } \\
\text { scanner 3D. }\end{array}$ & Good \\
\hline
\end{tabular}
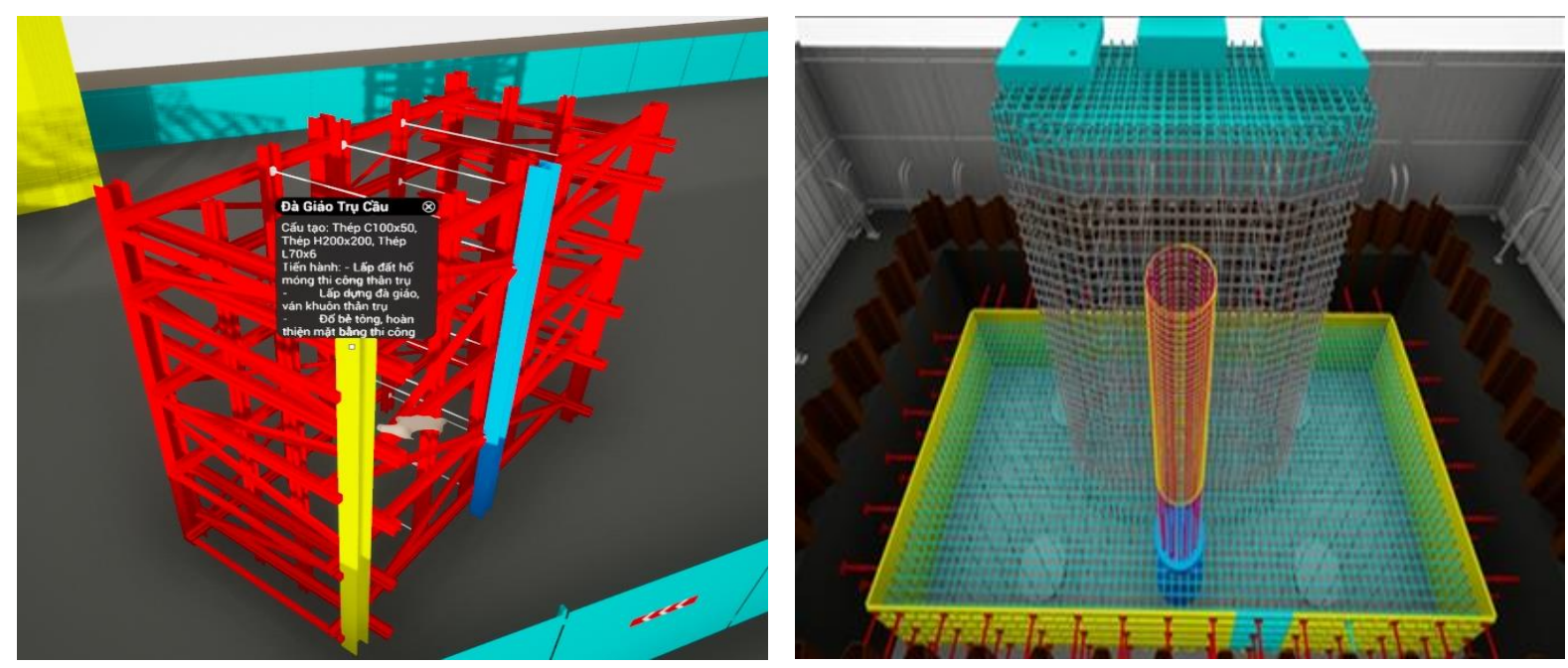

Figure 4. Virtual reality model (VR) 550 - Binh Duong overpass [61].

\section{CONCLUSION}

Using Building Information Modeling (BIM) in correlation with emerging technologies for the management of infrastructure can help improve efficiency and safety level of information exchange, reduce maintenance costs and risks, and increase profits for stakeholders. Having a comprehensive understanding of this technology helps owners, designers, and other project stakeholders select the best option of automated and strategic plans for enhanced management of the infrastructure network through project whole life cycle. Through analyzed projects, it can be seen that enterprises have made new strides to promote the application of BIM to infrastructure projects and achieve clear results such as shorten the schedule, save costs through optimization, handling of difficulties in each stage of construction, conflict control in post-construction processes, and operation. It is predicted that in the future, BIM will be the key to develop more efficient and cost-effective techniques for rehabilitating, strengthening, newing the transportation infrastructures in Vietnam. 
Transport and Communications Science Journal, Vol. 71, Issue 7 (09/2020), 760-774

\section{ACKNOWLEDGMENT}

We would like to thank the BROBIM Center, V7 Engineering \& Technology CO.LTD, and University of Transport and Communications for supporting this research.

\section{REFERENCES}

[1]. E. Charles et al., An Outline of the Building Descripition System, Institute of Physical Planning, Carnegie-Mellon University, (1974). https://files.eric.ed.gov/fulltext/ED113833.pdf

[2]. G.A, Van Nederveen, F.P. Tolman, Modeling multiple views on building, Automation in construction, 1 (1992) 215-224. http://dx.doi.org/10.1016/0926-5805(92)90014-B

[3]. National Institule of Building Sciences (NIBS), About the National BIM Standard United States, (2016). https://www.nationalbimstandard.org/about

[4]. Adam Strafaci, What does BIM mean for civil engineers? Road and highway projects can benefit from design using building information modeling, CE NEWS, 10 (2008).

[5]. T. H. Mai et al., Summary of experience in applying BIM in the world and current situation of BIM application in the construction industry in Vietnam, Journal of Construction Economics, 02 (2014) (in Vietnamese). http://dept.utc2.edu.vn/khoacongtrinh/Tin-cong-nghe/tong-hop-kinh-nghiemap-dung-bim-tren-the-gioi-va-hien-trang-ap-dung-bim-trong-nganh-xay-dung-viet-nam-40.html

[6]. QĐ 1057/QĐ-BXD, Temporary guidance for Building Information Modeling (BIM) application in pilot phase. (in Vietnamese)

[7]. QĐ 2500/QĐ-TTg, Decision approving the project of Building Information Modeling (BIM) application in construction activities and construction operation management, by Vietnamese gorverment. (in Vietnamese)

[8]. S.S. Chen, A.M. Shirole, Integration of information and automation technologies in bridge engineering and management: extending state of the art, J. Transp. Res. Board, 1976 (2006) 2-12. https://doi.org/10.1177/0361198106197600101

[9]. M. Mawlana, F. Vahdatikhaki, A. Doriani, A. Hammad, Integrating 4D modeling and discrete event simulation for phasing evaluation of elevated urban highway reconstruction projects, Autom. Constr, 60 (2015) 25-38. https://doi.org/10.1016/j.autcon.2015.09.005

[10]. M. Marzouk, M. Hisham, Implementing earned value management using bridge information modeling, KSCE Journal of Civil Engineering, 18 (2014) 1302-1313. https://doi.org/10.1007/s12205$\underline{014-0455-9}$

[11]. A.Z. Sampaio, Geometric modeling of box girder deck for integrated bridge graphical system, Automation in Construction, 12 (2003) 55-66. https://doi.org/10.1016/S0926-5805(02)00040-7

[12]. Karaman S. Gokhan, Stuart S. Chen, Benny J. Ratnagaran, Three-dimensional parametric data exchange for curved steel bridges, J. Transp. Res. Board, 2331 (2013) 27-34. https://doi.org/10.3141/2331-03

[13]. N. Okasha, D. Frangopol, Computational platform for the integrated life-cycle management of highway bridges, Eng. Struct, 33 (2011) 2145-2153. https://doi.org/10.1016/j.engstruct.2011.03.005

[14]. M. Marzouk, M. Hisham, A hybrid model for selecting location of mobile cranes in bridge construction projects, The Baltic Journal of Road and Bridge Engineering, 8 (2011) 184-189. https://doi.org/10.3846/bjrbe.2013.23

[15]. H. Lee, M. Lee, I. Lee, S. Nam, A study on the development of 3D parametric model for reinforced concrete bridge piers, Proc. in International Conference on Civil and Building Engineering Informatics (ICCBEI), (2017) 102-105. https://www.dropbox.com/s/jo05jlqh2y7v1of/proceedings\%20of\%20ICCBEI CCACHE\%202017.pdf $\underline{? \mathrm{dl}=0}$

[16]. C.S. Shim, N.R. Yun, H.H. Song, Application of 3D bridge information modeling to design and construction of bridges, Procedia Eng, 14 (2011) 95-99. https://doi.org/10.1016/j.proeng.2011.07.010 
[17]. C. Koch, S.G. Paal, A. Rashidi, Z. Zhu, M. Konig, I. Brilakis, Achievements and challenges in machine vision-based inspection of large concrete structures, Advances in Structural Engineering, 17 (2014) 303-318. https://doi.org/10.1260/1369-4332.17.3.303

[18]. P. Hüthwohl, R. Lu, I. Brilakis, Challenges of bridge maintenance inspection, Proc. in International Conference on Computing in Civil and Building Engineering (ICCCBE), (2016) 51-58. http://www.see.eng.osaka-u.ac.jp/seeit/icccbe2016/Proceedings/Full_Papers/006-215.pdf

[19]. G.D. Reeder, G.A. Nelson, 3D engineered models for highway construction: the Iowa experience, Rep. No. RB33-014, Iowa Department of Transportation, (2015). https://lib.dr.iastate.edu/intrans reports/130

[20]. B. Sankaran, J. France-Mensah, W. O'Brien, Data integration challenges for CIM in large infrastructure: a case study of Dallas Horseshoe Project, Proc. In International Conference on Computing in Civil and Building Engineering (ICCCBE), (2016) 1015-1022.

http://www.see.eng.osaka-u.ac.jp/seeit/icccbe2016/Proceedings/Full_Papers/128-075.pdf

[21]. S.M. Vick, I. Brilakis, A review of linear transportation construction progress monitoring techniques, Proc. in International Conference on Computing in Civil and Building Engineering (ICCCBE), (2016) 1106-1113. u.ac.jp/seeit/icccbe2016/Proceedings/Full_Papers/140-375.pdf

[22]. B. Riverio, M.J. Dejong, B. Conde, Automated processing of large point clouds for structural health monitoring of masonry arch bridges, Automation in Construction, 72 (2016) 258-268. https://doi.org/10.1016/j.autcon.2016.02.009

[23]. N. P. Thien, T. Q. Huy, BIM story in Vietnam and experience from UK, Architectural magazine, 05 (2017). (in Vietnamese) https://www.tapchikientruc.com.vn/chuyen-muc/cau-chuyen-bim-o-vietnam-va-kinh-nghiem-tu-anh-quoc.html.

[24]. H. X. Tin et al., Research on modeling of bridge construction information for the structural design step of overpass bridge at intersection 550 - Binh Duong, Proceedings of UTC scientific research of the year $2018-2019,2019$.

[25]. FHWA-HIF-16-011, Bridge Information Modeling Standardization Volume I: Information Exchange, U.S Department of Transportation Federal Highway Administration, 2016. https://www.fhwa.dot.gov/bridge/pubs/hif16011/hif16011b.pdf

[26]. P. T. Huan, N. D. Tien, Applying construction information modeling in bridge project implementation, Transporation journal, (2016) 5 pages.

[27]. Autodesk, BIM for Infrastructure: A vehicle for business transformation, Autodesk (2012). https://www.my-morpheus.com/UserFiles/file/bim-vehicle-for-business-transformationwhitepaper-en.pdf

[28]. M. Breunig, A. Borrmann, E. Rank, S. Hinz, T. Kolbe, M. Schilcher, Collaborative multi-scale 3D city and infrastructure modeling and simulation, Proc. in The International Archives of the Photogrammetry, Remote Sensing and Spatial Information Sciences, XLII-4/W4 (2017) 341-352. https://doi.org/10.5194/isprs-archives-XLII-4-W4-341-2017

[29]. S.A. Jones, D. Laquidara-Carr, The business value of BIM for infrastructure, SmartMarket report, Rep. to Dodge Data \& Analytics, Balford, MA, 2017. http://images.autodesk.com/adsk/files/business value of bim for infrastructure smartmarket report 2012.pdf

[30]. T. Kageyama, Preliminary verification of the effects of introduction of CIM in the detailed design phase of bridge, Proc. in International Conference on Computing in Civil and Building Engineering (ICCCBE), (2016) 1031-1037. http://www.see.eng.osakau.ac.jp/seeit/icccbe2016/Proceedings/Full_Papers/130-174.pdf

[31]. H.T. Abdelwahab, Intelligent design (4D, 5D and beyond) for road design and construction projects: Two case studies, International Road Federation (IRF) Examiner, 12 (2017) 21-25. https://www.irf.global/ebooks/IRF-Examiner-17Vol12.pdf 
[32]. P. Pakkala, J. Myllymaa, J. Sireeni, Benefits of virtual design and construction in civil engineering in the Nordics, International Road Federation (IRF) Examiner, 12 (2017) 27-31.

https://www.irf.global/ebooks/IRF-Examiner-17Vol12.pdf

[33]. H.M. Shin, H.M. Lee, S.J. Oh, J.H. Chen, Analysis and design of reinforced concrete bridge column based on BIM, Procedia Eng, 14 (2011) 2160-2163, https://doi.org/10.1016/j.proeng.2011.07.271

[34]. A. Borrmann, Y. Ji, J. Jubierre, M. Flurl, Procedural modeling: A new approach to multi-scale design in infrastructure projects, Proc. in EG-ICE Workshop on Intelligent Computing in Civil Engineering, Herrsching, Germany, (2012) 1-10. http://www.cie.bv.tum.de/publications/proceedings/20120704 Borrmann et al EGICE.pdf

[35]. Y. Ji, A. Borrmann, J. Beetz, M. Obergrießer, Exchange of parametric bridge models using a neutral data format, Journal of Computing in Civil Engineering, 27 (2013) 593-606. https://doi.org/10.1061/(ASCE)CP.1943-5487.0000286

[36]. W. Liu, H. Guo, H. Li, Y. Li, Using BIM to improve the design and construction of bridge projects: a case study of a long-span steel-box arch bridge project, Int. J. Adv. Robot. Syst, 11 (2014) 1-11. https://doi.org/10.5772/58442

[37]. M. Marzouk, M. Hisham, S. Ismail, M. Youssef, O. Seif, On the use of building information modeling in infrastructure bridges, Proc. in 27th International Conference Applications of IT in the AEC Industry (CIB W78), (2010) 1-10. http://itc.scix.net/cgi-bin/works/Show?w78-2010-135

[38]. N. Ali, S. Chen, R. Srikonda, H. Hu, Development of concrete bridge data schema for interoperability, Transportation Research Record: Journal of the Transportation Research Board, 2406 (2014) 87-97. https://doi.org/10.3141/2406-10

[39]. Y. Sugita, T. Kawaguchi, K. Hatanaka, H. Shimbo, M. Yamamura, Y. Kobayashi, Y. Fujisawa, I. Kobayashi, N. Yabuki, Development of a design support system for geological disposal using a CIM concept, Proc. in International Conference on Computing in Civil and Building Engineering (ICCCBE), (2016) 1173-1182. http://www.see.eng.osakau.ac.jp/seeit/icccbe2016/Proceedings/Full Papers/148-365.pdf

[40]. L.R. Tawelian, S.B. Mickovski, The implementation of geotechnical data into the BIM process, Procedia Eng, 143 (2016) 734-741. https://doi.org/10.1016/j.proeng.2016.06.115

[41]. S. Vilgertshofer, A. Borrmann, Using graph rewriting methods for the semi automatic generation of parametric infrastructure models, Adv. Eng. Inform, 33 (2017) 502-515. https://doi.org/10.1016/j.aei.2017.07.003

[42]. A. Jootoo, D. Lattanzi, A machine learning based approach to bridge design prototyping, Proc. in International Conference on Computing in Civil and Building Engineering (ICCCBE), (2016) 18461852. https://doi.org/DS31_1568FPA

[43]. J. Bien, Modelling of structure geometry in bridge management systems, Arch. Civil Mech. Eng, 11 (2011) 519-532. https://doi.org/10.1016/S1644-9665(12)60099-5

[44]. H. Li, N. Chan, T. Huang, M. Skitmore, J. Yang, Virtual prototyping for planning bridge construction, Autom. Constr, 27 (2012) 1-10. https://doi.org/10.1016/j.autcon.2012.04.009

[45]. S.F. Huang, C.H. Chen, R.J. Dzeng, Design of track alignment using building information modeling, J. Transp. Eng, 137 (2011) 823-830. https://doi.org/10.1061/(ASCE)TE.1943$\underline{5436.0000287}$

[46]. N. Kodama, R. Fujita, Study of standard of LOD/LOI toward implementing CIM in Japan, Proc. in International Conference on Civil and Building Engineering Informatics (ICCBEI), (2017) 106109. https://www.dropbox.com/s/jo05jlqh2y $7 \mathrm{v} 1$ of/proceedings\%20of\%20ICCBEI_CCACHE $\% 202017 . p d f ? d l=0$

[47]. A. Hammad, C. Zhang, Y. Hu, E. Mozaffari, Mobile model-based bridge lifecycle management system, Comput. Aided Civ. Inf. Eng, 21 (2006) 530-547. https://doi.org/10.1111/j.1467$\underline{8667.2006 .00456 . x}$ 
[48]. B. Fanning, C.M. Clevenger, M.E. Ozbek, H. Mahmoud, Implementing BIM on infrastructure: comparison of two bridge construction projects, Pract. Period. Struct. Des. Constr, 20 (2014) 1-8. https://doi.org/10.1061/(ASCE)SC.1943-5576.0000239

[49]. K.M. Lee, Y.B. Lee, C.S. Shim, K.L. Park, Bridge information models for construction of a concrete box-girder bridge, Structure and Infrastructure Engineering, 8 (2012) 687-703. https://doi.org/10.1080/15732471003727977

[50]. M. Marzouk, M. Hisham, S. Ismail, M. Youssef, O. Seif, On the use of building information modeling in infrastructure bridges, Proc. in 27th International Conference Applications of IT in the AEC Industry (CIB W78), (2010) 1-10. http://itc.scix.net/cgi-bin/works/Show?w78-2010-135

[51]. S.M. Vick, I. Brilakis, A review of linear transportation construction progress monitoring techniques, Proc. in International Conference on Computing in Civil and Building Engineering (ICCCBE), (2016) 1106-1113. http://www.see.eng.osakau.ac.jp/seeit/icccbe2016/Proceedings/Full_Papers/140-375.pdf

[52]. H. Hu, S.S. Chen, R. Srikonda, N. Ali, Development of alignment-based parametric data exchange schema for bridge geometry, J. Transp. Res. Board, 2460 (2014) 22-30. https://doi.org/10.3141/2460-03

[53]. M. Elnabwy, M. Kaloop, E. Elbeltagi, Talkha steel highway bridge monitoring and movement identification using RTK-GPS technique, Measurement, 46 (2013) 4282-4292. https://doi.org/10.1016/j.measurement.2013.08.014

[54]. L. H. Nam et al., BIM for technical infrastructure projects in Vietnam: Current status, application barriers and solutions, Journal of construction science and technology, 12 (2018) 53-59. (in Vietnamese)

[55]. Chien K.F, Wu Z.H, Huang S.C, Identifying and assessing critical risk factors for BIM projects: Empirical study, Automation in Construction, (45) (2014) 15. https://doi.org/10.1016/j.autcon.2014.04.012

[56]. Aladag H, Demirdogenm G, Isik Z, Building Information Modeling (BIM) Use in Turkish $\begin{array}{llllll}\text { Construction } & \text { Industry, } & \text { Procedia } & \text { Engineering, } & 161 & \text { (2016) }\end{array}$ https://doi.org/10.1016/j.proeng.2016.08.520

[57]. Ku, K, Taiebat M, BIM Experiences and Expectations: The Constructors' Perspective, International Journal of Construction Education and Research, 7 (2011) 175-197. https://doi.org/10.1080/15578771.2010.544155

[58]. Volk R, Stengel J, Scotsman F, Building Information Models (BIM) for existing buildingsliterature review and future needs, Automation in Construction, 38 (2014) 109-127. https://doi.org/10.1016/j.autcon.2013.10.023

[59]. Jones S.A, Laquidara-Carr D, The Business Value of BIM for Infrastructure 2017, in SmartMarket Report, Dodge Data \& Analytics, 2017. https://www.construction.com/toolkit/reports/the-business-value-of-BIM-for-infrastructure-2017 [60]. N. T. Thuy et al., BIM application for Thu Thiem 2 Bridge in construction engineering design phase, International conference on Application of Artificial Intelligence in Transportation, (2020).

[61]. H. X. Tin et al., 550 - Binh Duong overpass using Building Information Modeling, International conference on Application of Artificial Intelligence in Transportation, (2020). 